\title{
Influence of Ionizing Radiation on Echis pyramidium Snake Venom: Biochemical and Immunological Aspects
}

\author{
*Adel G. El-Missiry, ***Esmat A. Shaban, **Mohamed R. Mohamed, *Ahmed A. \\ Ahmed, **Nadia M. Abdallah and *Manal I. Moustafa \\ *Medical Research Center - faculty of medicine Ain Shams University. \\ ** Department Of biochemistry - Faculty of Science Ain Shams University \\ ****Department of Drug Radiation Research - National Center for Radiation Research \\ and Technology - Atomic Energy Authority
}

\begin{abstract}
The effect of a single $\mathrm{LD}_{50}$ dose of native Echis pyramidum venom $(27.69 \mu \mathrm{g} / \mathrm{mouse})$ on the activities of certain serum enzymes levels: aspartate aminotransferase (AST), alanine aminotransferase (ALT), alkaline phosphatase (ALP), urea, creatinine, lactate dehydrogenase $(\mathrm{LDH})$, creatine phosphokinase (CPK), creatine kinase isoenzyme (CK-MB) were studied. Samples from the serum were collected $4 \mathrm{hr}$ following LD50 venom dose intraperitonealy injected in male Swiss albino mice. The activities of these enzymes showed significant elevation compared to the non-envenomated group. In contrast, an equivalent dose of $1.5 \mathrm{kGy} \gamma$ irradiated
\end{abstract}

Echis pyramidum venom $(27.69 \mu \mathrm{g} /$ mouse $)$ did not cause any significant increase compared to non-envenomated group.

The effect of a dose that is equivalent to $1 / 2 \operatorname{LD}_{50}(13.8 \mu \mathrm{g} / 50 \mu \mathrm{l})$ of native Echis pyramidum venom on plasma creatine phosphokinase (CPK) induced a significant increase of creatine phosphokinase $(\mathrm{CPK})$ level compared to normal control $(\mathrm{P}<0.01)$. In contrast, an equivalent dose of $1.5 \mathrm{kGy} \gamma$ irradiated Echis pyramidum venom showed non significant difference in creatine phosphokinase activity when compared to the normal control. Light microscopic examinations of gastrocenemius muscles of mice injected with native Echis pyramidum venom $\left(1 / 2 \mathrm{LD}_{50} ; 13.8 \mu \mathrm{g} / 50 \mu \mathrm{l}\right)$ showed fragmentation, disorganization, loss of myofibrils in some of the muscle fibers, hemorrhage in-between the muscle fibers and mononuclear cellular infiltration. While light microscopic examinations of gastrocenemius muscles of mice injected with $1.5 \mathrm{kGy}$ $\gamma$ irradiated Echis pyramidum venom $(13.8 \mu \mathrm{g} / 50 \mu \mathrm{l}$; a dose identical to that used from native venom) showed that most muscle fibers were of normal appearance except for small area of fragmentation and disorganized myofibrils and oedema of the intercellular connective tissue.

Double immunodiffusion test revealed a similar reactivity for native, $1 \mathrm{kGy}, 1.5 \mathrm{kGy}$ and $3 \mathrm{kGy}$ $\gamma$ irradiated Echis pyramidum venoms against a commercial polyvalent Egyptian antivenin. The visible lines obtained in the immunodiffusion reactions were identical and joined smoothly at the corners, indicating that there was no change in their antigenic reactivity. These results demonstrate that the ability of the venom antigens to react with its corresponding antibodies was maintained in spite of being exposed to radiation doses of $1 \mathrm{kGy}, 1.5 \mathrm{kGy}$ and $3 \mathrm{kGy}$.

Both antivenins raised against native or $1.5 \mathrm{kGy} \gamma$ irradiated venoms recognized Echis pyramidum venom when submitted to protein blotting, but the anti $1.5 \mathrm{kGy} \gamma$ irradiated venom show a higher intensity bands than the antivenin raised against native Echis pyramidum venom, in spite of having less neutralizing activity (native neutralize $50 \mathrm{LD}_{50}, 1.5 \mathrm{kGy} \gamma$ irradiated neutralize $40 \mathrm{LD}_{50}$ ), this indicates that antibodies were formed not only for toxic fraction but also for non toxic fraction.

Irradiation of the whole Echis Pyramidium Venom with $1.5 \mathrm{KGy}$ reduced its lethality 12.5 times though keeping its immunogenicity. The $1.5 \mathrm{KGy}$ dose was shown to be the best radiation dose to promote detoxification without significantly affecting its immunogenicity. Thus results of this study confirm the conclusion that $\gamma$ radiation is a suitable way to detoxify Echis Pyramidium Venom without affecting its immunogenicity provided that proper dose is used. 
Keywords: Echis pyramidum, $\gamma$ irradiated venom, aspartate aminotransferase, alanine aminotransferase, alkaline phosphatase, urea, creatinine, lactate dehydrogenase, creatine phosphokinase, creatine kinase isoenzyme, Double immunodiffusion, protein blotting.

\section{Introduction}

There are variations in the pharmacological, antigenic and biochemical properties of the different snake venoms, both between species and within a single species due to geographic and ontogenetic variables (S'anchez et al., 1992).

According to Aguiyi et al. (2001), the effect of lethal Echis carinatus venom on serum enzyme levels and blood plasma coagulation parameters in rats subjected to intraperitoneal (i.p) venom injection, measurements of the enzyme and coagulation parameter levels $4 \mathrm{~h}$ after venom administration showed an increase in the level of enzymes; lactate dehydrogenase (LDH), ALT and creatinine kinase (CK) as well as a change in the level of coagulation parameters D-Dimer and Quick due to envenomation.

Also, it has been reported that treatment of Swiss albino rats with a sublethal dose of Cearates cearastes venom $(0.75 \mu \mathrm{g} / \mathrm{g}$ body weight) increased significantly the activities of lactate dehydrogenase, isocitrate dehydrogenase and aldolase in the serum, liver and skeletal muscle $0.5-6 \mathrm{~h}$ postenvenomation (Abu-Sinna et al., 1992). Moreover, this treatment induced hypoglycemia after $15 \mathrm{~min}$ which persisted for $24 \mathrm{~h}$ (Abu-Sinna et al., 1993) and increased the plasma total protein level significantly, while it decreased the liver and skeletal muscle protein contents 15-24 $\mathrm{h}$ after envenomation (Abdel-Aal et al., 1992).

Artashes and Silva (2006) reported that venom of the Armenian adder (Vipera raddei Boettger, 1890) was tested for its ability to induce histopathological changes in rabbits after long-term (once every 6 days for 30 days) intramuscular injection of the venom $(0.35 \mathrm{mg} / \mathrm{kg}$ b.w.; approx. 0.5 LD50), induced moderate histopathological changes in vital organs (liver, heart, kidney, adrenal, lung and spleen).

In Brazil, gamma rays have been employed to detoxify Brazilian snake venoms in order to improve antivenin production. Murata $e t$ al. (1990) irradiated Crotalus durissus terrificus venom with gamma rays using different doses and found that 2,000 Gy was a good compromise in irradiation dosage for venom solutions, which promoted significant venom detoxification, yet maintained many of the venom original immunological properties. In 2000, Gallacci et al. studied other snake venoms such as Bothrops jararacussu and Lachesis muta venoms and carried out some experiments using bee venom with good results of detoxification when subjected to the effects of gamma rays.

In 2003, Bennacef-Heffar and LarabaDjebari studied the effect of gamma irradiation on the venom of Vipera lebetina (one of the two widespread snakes in Algeria). Vipera lebetina venom was irradiated with two doses of gamma rays (1 and $2 \mathrm{kGy}$ ) from a ${ }^{60} \mathrm{Co}$ source, and the venom's toxic, enzymatic, and structural properties were analyzed. The immunogenic properties of the irradiated venom were preserved and the antisera obtained were able to neutralize the toxic effect of Vipera lebetina native venom. These results indicate that irradiation of Vipera lebetina venom with a dose of 2 kGy can promote a significant detoxification while keeping the immunological properties intact.

In 2002, Souza et al., investigated the ability of gamma radiation from ${ }^{60} \mathrm{Co}(2000$ Gy) to attenuate the toxic effects of Bothrops jararacussu venom on mouse neuromuscular preparations in vitro. These findings support the hypothesis that gamma irradiation could be an important tool to improve antisera production by reducing toxicity while preserving immunogenicity.

It was reported recently that intravenous administration of antivenin, prepared from $\mathrm{IgG}$ of venom immunized horses or sheep, is the only effective treatment of systemic envenoming (Harrison et al., 2006). 
It has been suggested in the past that detoxified venoms can be used to produce antiserum as an effort to protect the animals from the venom toxicity. It is therefore important to be sure that the detoxified venoms do not lose their immunogenicity. Several techniques have been used to detoxify venoms, such as mixing the venom with carboxymethylcellulose (Moroz et al., 1963), irradiation by gamma rays (Baride et al., 1980), adding formaldehyde (Costa et al., 1985), controlled iodination (Daniel et al., 1987) and encapsulation of purified toxins in liposomes (Freitas and Frezard, 1997). One method that has been shown to be effective for attenuating venom toxicity and maintaining immunogenicity is $\gamma$ irradiation (Nascimento et al., 1996).

Proteins irradiated, either in dry state or in solution, undergo chemical and physicochemical changes that can alter their primary, secondary and tertiary structures, while keeping many of their native immunological properties intact ( Skalka and Antoni, 1970).

In this study the effects of gamma irradiation on the venom of Echis pyramidum was determined. Venom was irradiated with $1.5 \mathrm{KGy}$ and $3 \mathrm{KGy}$ from ${ }^{60} \mathrm{Co}$ source and the venom's toxic, enzymatic and immunological properties were analyzed.

\section{Material and methods}

\section{- Venom}

Venom used in this study was that of the Egyptian Viper Echis pyramidum and was obtained from Laboratory Animal Unit of Medical Research Center, Faculty of medicine, Ain Shams University.

\section{- Antivenin}

Egyptian polyvalent antivenin obtained from the Egyptian Organization of Biological products and Vaccines, Agouza, Cairo, Egypt, was used. The lyophilized polyvalent antivenin produced in horses was kept at $4^{\circ} \mathrm{C}$ and reconstituted with saline $(20 \mathrm{mg} / \mathrm{ml})$ before use.

\section{- Irradiation facilities}

The Echis pyramidum venom was irradiated with $1 \mathrm{kGy}, 1.5 \mathrm{kGy}$ and $3 \mathrm{kGy} \gamma$ rays in the National Center for Radiation Research andTechnology, Cairo, Egypt, using cobalt-60 gamma cell 220, manufactured by the atomic energy of Canada (AECL). The radiation dose rate was $1.4 \mathrm{Rad}$ per second.

Throughout this study 45 males Swiss albino mice weighing 20-25 gm were allocated to the following groups:

1- Control (non envenomated) group $(\mathrm{n}=15)$. Received $0.5 \mathrm{ml}$ intraperitoneal injection of saline.

2- Native Echis pyramidum venom envenomated group $(\mathrm{n}=15)$. Received a dose of $27.7 \mu \mathrm{g}$ (in $0.5 \mathrm{ml}$ saline) per mouse.

3- $1.5 \mathrm{kGy} \gamma$ irradiated Echis pyramidum venom envenomated group $(n=15)$. Received dose of $27.7 \mu \mathrm{g}$ (in $0.5 \mathrm{ml}$ saline) per mouse.

Native and 1.5 kGy $\gamma$ irradiated Echis

pyramidum venom $(27.7 \mu \mathrm{g})$ dissolved in $0.5 \mathrm{ml}$ of saline, was injected (i.p.) into two groups of 15 mice each. Control group received $0.5 \mathrm{ml}$ i.p. injection of saline. After $4 \mathrm{~h}$, blood samples were collected and centrifuged to obtain serum.

\section{- Lethality}

The $\mathrm{LD}_{50}$ of native and irradiated venoms were determined according to the method of Reed and Muench (1938), using male albino Swiss mice 20-25 gm. Ascending concentrations of 5 dose levels of the freshly prepared venom solutions were arranged in a geometric progression by using increasing factor equal 1.2 starting by a dose which kills approximately $0-10 \%$ of the animals and ending by a dose which kills approximately 90-100 \% of the injected animals. Each dose level was tested in 5 mice, and all injections were given intraperitoneally, and deaths or survivals of envenomated animals were recorded after $24 \mathrm{hs}$ from the time of the injection.

\section{- Preparation of antivenin in rabbits}

Adult male rabbits weighing $3-3.5 \mathrm{Kg}$ were maintained under standard conditions of boarding and given standard food were divided into 2 groups: 
1- Rabbits received native intradermal multisits injection of Echis Pyramidum venom $(n=3)$

2- Rabbits received intradermal multisits injection of $1.5 \mathrm{kGy} \gamma$ irradiated Echis
Pyramidum venom $(\mathrm{n}=3)$.

Immunization was done in the presence or absence of complete (CFA) or incomplete (IFA) Freund's adjuvant according to table 1.

Table (1): Immunization schedule for rabbits using either native or $1.5 \mathrm{kGy} \gamma$ irradiated Echis pyramidum venom.

\begin{tabular}{|l|l|l|l|}
\hline Week & $\begin{array}{l}\text { Native } \\
\text { venom }(\mu \mathrm{g})\end{array}$ & $\begin{array}{l}1.5 \mathrm{kGy} \gamma \text { irradiated } \\
\text { venom } \\
(\mu \mathrm{g})\end{array}$ & Freund's adjuvant \\
\hline 0 & 500 & 1000 & CFA \\
\hline 2 & 500 & 1000 & CFA \\
\hline 4 & 1000 & 2000 & IFA \\
\hline 6 & 1200 & 2400 & - \\
\hline 8 & 1200 & 2400 & - \\
\hline 10 & 1500 & 3000 & - \\
\hline
\end{tabular}

By the end of this schedule serum was obtained from the two rabbit groups and tested for Protein blotting

\section{Measured parameters}

Determination of serum ALT and AST activities were carried out by (Reitman and Frankel, 1957). Serum alkaline phosphatase activity (ALP) was determined in serum. The ALP was performed kinetically using a test reagent kit according to the method of Rec. GSCC,(1972). Determination of serum urea was carried out by (Patton and Crouch, 1977), serum creatinine activity was carried out by using the method of (Henry, 1974), serum LDH was carried out by using the method of (IFCC, 1980), serum (CPKMB) was carried out according to the methos of Rec. GSCC. (1978), Serum creatine kinase isoenzyme (CK-MB) was carried out by an immunoinhibition method (Szasz and Busch, 1979)

\section{- Myotoxic activity.}

Myotoxic activity of the native and $1.5 \mathrm{kGy}$ $\gamma$ irradiated Echis pyramidum venom was determined in mice according to Yongming Bao et al., (2005).

Throughout this study 12 male albino Swiss mice weighing 20-25 gm were allocated in the following groups:
1- Control group: Untreated non envenomated mice only received $0.5 \mathrm{ml}$ intraperitoneal injection of saline.

2- Native Echis pyramidum venom envenomated group.

3- $1.5 \mathrm{kGy} \gamma$ irradiated Echis pyramidum venom envenomated group.

Native and 1.5 kGy $\gamma$ irradiated Echis pyramidum venom $1 / 2$ LD50 $(13.8 \mu \mathrm{g})$, was dissolved in $50 \mu 1$ of saline and injected into two groups of four mice each in their left gastrocenemius muscle. A control group of 4 mice received $50 \mu \mathrm{l}$ of saline. After $3 \mathrm{~h}$, blood samples were collected and creatine phosphokinase (CPK) levels in plasma were determined.

\section{- Histological changes}

In addition to CPK activity measurements, formalin fixed muscle tissue samples were obtained after $3 \mathrm{~h}$, and processed for histological evaluation of muscle damage. Sections of the muscles were Dehydrated and cleared in ascending grades of ethyl alcohol and xylene respectively. The specimens are then embedded in paraffin wax. Sections of 5 microns thickness were cut and stained with haematoxyline and eosin and examined under light microscope 
according to the method of Drury and Wallington (1976).

\section{- Double immunodiffusion}

Immunodiffusion experiments were carried out as originally described by Ouchterlony (1945).

\section{- Protein blotting}

Western Blot method described by Towbin et al. (1979) which results in efficient and reproducible electrophoretic protein transfer from polyacrylamide gels onto polyvinylidene difluoride (PVDF) membrane, was applied.

\section{Statistical Analysis of Data:}

The statistical analysis was performed using student $\mathrm{t}$ - test by Prism Dimo- program and origin 6.1. the method used for the analysis of the results is that given by Millon et al., (1986)

\section{Results}

1- Effect of native and $1.5 \mathrm{kGy} \gamma$ irradiated Echis pyramidum venoms on liver tests:

(tab.2, fig. 1) show the differences in the mean values for ALT, AST and ALP among the different groups. These results demonstrated that i.p injection of an $\mathrm{LD}_{50}$ dose $(27.69 \mu \mathrm{g} /$ mouse) of native Echis pyramidum venom induced a highly significant increase in ALT, AST and ALP compared to non-envenomated control $(\mathrm{P}<0.001)$.

In contrast, an equivalent dose of $1.5 \mathrm{kGy} \gamma$ irradiated Echis pyramidum venom (27.69

$\mu \mathrm{g} /$ mouse) did not cause any significant change in ALT, AST or ALP compared to the normal non-envenomated control. Moreover, the increase in the level of ALT, AST and ALP in case of intraperitoneal injection of native Echis pyramidum venom was highly significant compared to intraperitoneal injection of $1.5 \mathrm{kGy} \gamma$ irradiated Echis pyramidum venom $(\mathrm{P}<0.001)$.

2- Effect of native and $1.5 \mathrm{kGy} \gamma$ irradiated Echis pyramidum venoms on kidney tests:

(Tab. 3, fig. 2) show the differences in the mean values for urea and creatinine among the different groups. These results demonstrated that i.p injection of an $\mathrm{LD}_{50}$ dose $(27.69 \mu \mathrm{g} / \mathrm{mouse})$ of native Echis pyramidum venom induced a highly significant increase in urea and creatinine compared to non-envenomated control $(\mathrm{P}<0.001)$.

In contrast, an equivalent dose of $1.5 \mathrm{kGy} \gamma$ irradiated Echis pyramidum venom (27.69

$\mu \mathrm{g} /$ mouse) did not cause any significant change in urea or creatinine compared to non-envenomated control. Moreover, the increase in the level of urea and creatinine in case of i.p injection of native Echis pyramidum venom was highly significant compared to that in case of i.p injection of $1.5 \mathrm{kGy} \gamma$ irradiated Echis pyramidum

3- Effect of native and $1.5 \mathrm{kGy} \gamma$ irradiated Echis pyramidum venoms on heart tests:

(tab. 4, fig. 3) show the differences in the mean values for $\mathrm{LDH}, \mathrm{CPK}$ and CK-MB among the different groups. These results demonstrated that i.p injection of an $\mathrm{LD}_{50}$ dose $(27.69 \mu \mathrm{g} /$ mouse) of native Echis pyramidum venom induced a highly significant increase in LDH, CPK and CKMB compared to non-envenomated control $(\mathrm{P}<0.001)$.

In contrast, an equivalent dose of $1.5 \mathrm{kGy} \gamma$ irradiated Echis pyramidum venom (27.69

$\mu \mathrm{g} /$ mouse) did not cause any significant increase in $\mathrm{LDH}, \mathrm{CPK}$ or CK-MB compared to non-envenomated control. Moreover, the increase in the level of LDH, CPK and CK-MB in case of i.p injection of native Echis pyramidum venom was highly significant compared to that in case of i.p injection of $1.5 \mathrm{kGy} \gamma$ irradiated Echis pyramidum venom $(\mathrm{P}<0.001)$.

\section{4- Myotoxic activity:}

(Tab. 5 , fig 4) show the effect of a dose that is equivalent to $1 / 2 \operatorname{LD}_{50}(13.8 \mu \mathrm{g} / 50 \mu \mathrm{l})$ of native Echis pyramidum venom on plasma creatine phosphokinase (CPK) levels. Native Echis pyramidum venom induced a significant increase of creatine phosphokinase (CPK) of the gastrocenemius muscles compared to normal control $(\mathrm{P}<0.01)$. In contrast, an equivalent dose of $1.5 \mathrm{kGy} \gamma$ irradiated 
Echis pyramidum venom did not show any significant increase of creatine phosphokinase when compared to control. Moreover, the observed increase in CPK following injection of native Echis pyramidum venom was significantly higher than that observed following injection of the $1.5 \mathrm{kGy} \gamma$ irradiated venom $(\mathrm{P}<0.01)$.

\section{5- Histological changes}

Fig. (5) shows a light microscopic examination of gastrocenemius muscles of mice injected with saline (normal control). It shows bundles of skeletal muscle fibers with evident cross striations and peripherally situated multiple nuclei.

Fig. 6 (A) and (B) show light microscopic examinations of gastrocenemius muscles of mice injected with native Echis pyramidum venom $\left(1 / 2 \mathrm{LD}_{50} ; 13.8 \mu \mathrm{g} / 50 \mu \mathrm{l}\right)$. They show fragmentation, disorganization, loss of myofibrils in some of the muscle fibers, hemorrhage in-between the muscle fibers and mononuclear cellular infiltration.

Fig. 7 (A) and (B) show light microscopic examinations of gastrocenemius muscles of mice injected with $1.5 \mathrm{kGy} \gamma$ irradiated
Echis pyramidum venom $(13.8 \mu \mathrm{g} / 50 \mu \mathrm{l}$; a dose identical to that used from native venom). They show most of the muscle fibers were of normal appearance except for small area of fragmentation and disorganized myofibrils and oedema of the intercellular connective tissue.

\section{6- Double immunodiffusion}

The immunogenic reactivity of the native, 1, 1.5 and 3 kGy $\gamma$ irradiated Echis pyramidum venoms to commercial horse polyvalent Egyptian antivenin was tested using the double immunodiffusion method fig. (8). All tested venoms showed similar reactivity. The visible lines obtained in the double immunodiffusion reactions were identical and joined smoothly at the corners, indicating that there was no change in the antigenic determinants.

\section{7- Western blotting analysis}

By analyzing the Western blotting profiles Fig. (9), it was observed that the antivenin raised against the native and the $1.5 \mathrm{kGy} \gamma$ irradiated Echis pyramidum venom recognized equally all the bands present on the native Echis pyramidum venom.

Table (2): The mean values of serum levels of alanine transaminase (ALT), aspartate transaminase (AST) and alkaline phosphatase (ALP) for normal control, native and $1.5 \mathrm{kGy} \gamma$ irradiated Echis pyramidum venom $(27.69 \mu \mathrm{g} / \mathrm{mouse})$ envenomated groups (4hr after i.p injection of mice $),(n=15)$.

\begin{tabular}{|c|c|c|c|}
\hline$\underbrace{\text { Groups }}_{\text {Parameters }}$ & Control & Native venom & $1.5 \mathrm{kGy}$ \\
\hline $\begin{array}{l}\text { ALT }(\mathrm{U} / \mathrm{L}) \\
\text { Mean } \pm \text { S.E. } \\
\% \text { change } \\
\text { P Value } \\
\text { P1 Value }\end{array}$ & $59.1 \pm 3$ & $\begin{array}{l}161.7 \pm 4.9 \\
+173.6 \\
P<0.001^{* *}\end{array}$ & $\begin{array}{l}67.4 \pm 2.7 \\
+14 \\
\text { N.S. } \\
P<0.001^{\text {** }}\end{array}$ \\
\hline $\begin{array}{l}\text { AST }(\mathrm{U} / \mathrm{L}) \\
\text { Mean } \pm \text { S.E. } \\
\% \text { change } \\
\text { P Value } \\
\text { P1 Value }\end{array}$ & $228.3 \pm 4.7$ & $\begin{array}{l}377.8 \pm 9 \\
+65.4 \\
P<0.001^{* *}\end{array}$ & $\begin{array}{l}238.1 \pm 4 \\
+4.2 \\
\text { N.S. } \\
P<0.001^{* *}\end{array}$ \\
\hline $\begin{array}{l}\text { ALP }(\mathrm{U} / \mathrm{L}) \\
\text { Mean } \pm \text { S.E. } \\
\% \text { change } \\
\text { P ValueP1 Value }\end{array}$ & $119.1 \pm 5.1$ & $\begin{array}{l}204 \pm 7.9 \\
+71.3 \\
P<0.001^{* *}\end{array}$ & $\begin{array}{l}129.8 \pm 4.9 \\
+8.9 \\
\text { N.S. } \\
P<0.001^{* *}\end{array}$ \\
\hline
\end{tabular}

P: Statistical difference from normal control. P1: Statistical difference from native venom. $P<0.001$ : highly significant. N.S.: Non significant. 
Table (3): The mean values of serum levels of urea and creatinine for normal control, native and $1.5 \mathrm{kGy} \gamma$ irradiated Echis pyramidum venom $(27.69 \mu \mathrm{g} /$ mouse) envenomated groups (4hr after i.p injection of mice), $(\mathrm{n}=15)$.

\begin{tabular}{|c|c|c|c|}
\hline $\begin{array}{l}\text { Groups } \\
\text { Parameters }\end{array}$ & Control & Native venom & $1.5 \mathrm{kGy}$ \\
\hline $\begin{array}{l}\text { Urea }(\mathrm{mg} / \mathrm{dl}) \\
\text { Mean } \pm \text { S.E. } \\
\text { \% change } \\
\text { P Value } \\
\text { P1 Value }\end{array}$ & $32.7 \pm 1.4$ & $\begin{array}{l}78.5 \pm 4 \\
+140 \\
P<0.001^{* *}\end{array}$ & $\begin{array}{l}35.8 \pm 1.5 \\
+9.4 \\
\text { N.S. } \\
P<0.001^{* *}\end{array}$ \\
\hline $\begin{array}{l}\text { Creatinine }(\mathrm{mg} / \mathrm{dl}) \\
\text { Mean } \pm \text { S.E. } \\
\% \text { change } \\
\text { P Value } \\
\text { P1 Value }\end{array}$ & $0.76 \pm 0.02$ & $\begin{array}{l}1.5 \pm 0.03 \\
+97.3 \\
P<0.001\end{array}$ & $\begin{array}{l}0.83 \pm 0.03 \\
+9.2 \\
\text { N.S. } \\
P<0.001^{* *}\end{array}$ \\
\hline
\end{tabular}

P: Statistical difference from normal control. P1: Statistical difference from native venom. $P<0.001$ : highly significant. $\quad$ N.S.: Non significant.

Table (4): The mean values of serum levels of lactate dehydrogenase (LDH), creatine kinase (CK) and creatine kinase isoenzyme (CK-MB) for normal control, native and $1.5 \mathrm{kGy} \gamma$ irradiated Echis pyramidum venom envenomated groups (4hr after i.p injection of mice), $(\mathrm{n}=15)$.

\begin{tabular}{|c|c|c|c|}
\hline Parameters & Control & Native venom & $1.5 \mathrm{kGy}$ \\
\hline $\begin{array}{l}\frac{\mathrm{LDH}(\mathrm{U} / \mathrm{L})}{\text { Mean } \pm \text { S.E. }} \\
\% \text { change } \\
\mathrm{P} \text { Value } \\
\mathrm{P} 1 \text { Value }\end{array}$ & $1672.5 \pm 28.4$ & $\begin{array}{l}2680.8 \pm 40.4 \\
+60.3 \\
P<0.001^{* *}\end{array}$ & $\begin{array}{l}1736.4 \pm 31.3 \\
+3.8 \\
\text { N.S. } \\
P<0.001^{* *}\end{array}$ \\
\hline $\begin{array}{l}\frac{\mathrm{CK}(\mathrm{U} / \mathrm{L})}{\text { Mean } \pm \mathrm{S} . \mathrm{E} .} \\
\% \text { change } \\
\mathrm{P} \text { Value } \\
\mathrm{P} 1 \text { Value }\end{array}$ & $670 \pm 15.4$ & $\begin{array}{l}1135.6 \pm 19 \\
+69.5 \\
P<0.001^{* *}\end{array}$ & $\begin{array}{l}719.5 \pm 12.7 \\
+7.3 \\
\text { N.S. } \\
P<0.001^{* *}\end{array}$ \\
\hline $\begin{array}{l}\text { CK-MB (U/L) } \\
\text { Mean } \pm \text { S.E. } \\
\% \text { change } \\
\text { P Value } \\
\text { P1 Value }\end{array}$ & $161.2 \pm 3.3$ & $\begin{array}{l}282.3 \pm 6.7 \\
+75.1 \\
P<0.001^{* *}\end{array}$ & $\begin{array}{l}170.9 \pm 2.4 \\
+6 \\
\text { N.S. } \\
P<0.001^{* *}\end{array}$ \\
\hline
\end{tabular}

P: Statistical difference from normal control. P1: Statistical difference from native venom. $P<0.001$ : highly significant. N.S.: Non significant. 


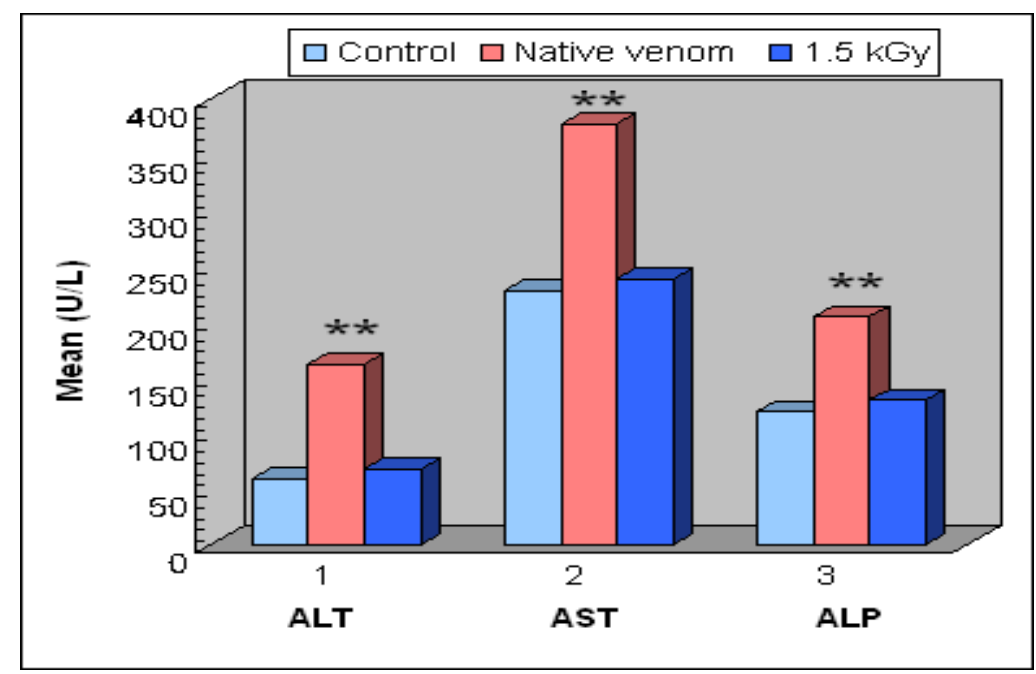

Fig. (1): The mean values of serum levels of alanine transaminase (ALT), aspartate transaminase (AST) and alkaline phosphatase (ALP) for normal control and native and $1.5 \mathrm{kGy}$ $\gamma$ irradiated Echis pyramidum venom envenomated groups (4h after i.p injection of mice), (n = 15). Each column represents the mean value of fifteen mice. **: Highly significant difference from normal control.

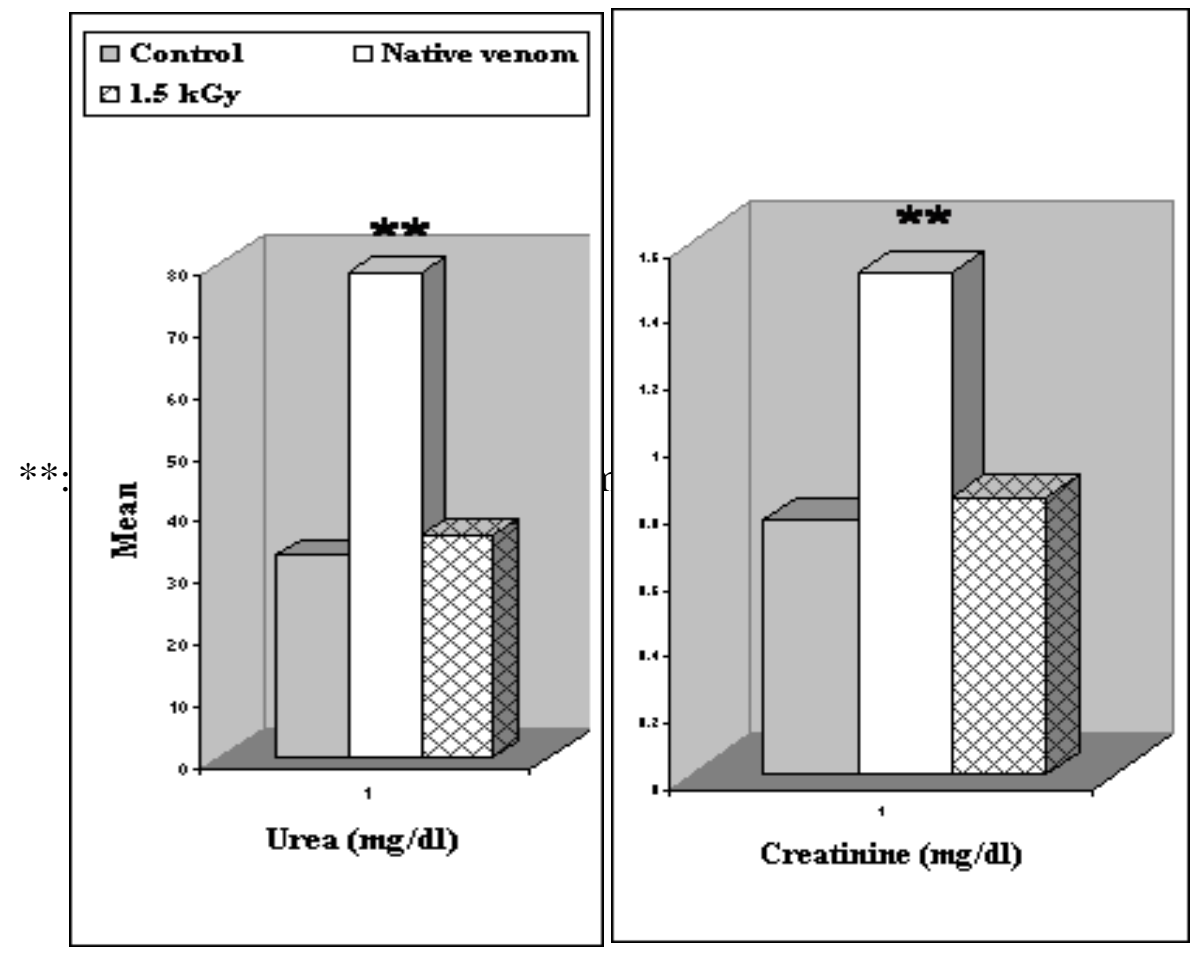

Fig. (2): The mean values of serum levels of urea and creatinine for normal control, native and $1.5 \mathrm{kGy} \gamma$ irradiated Echis pyramidum venom envenomated groups (4hr after i.p injection of mice). Each column represents the mean value of fifteen mice.

**: Highly significant difference from normal control. 


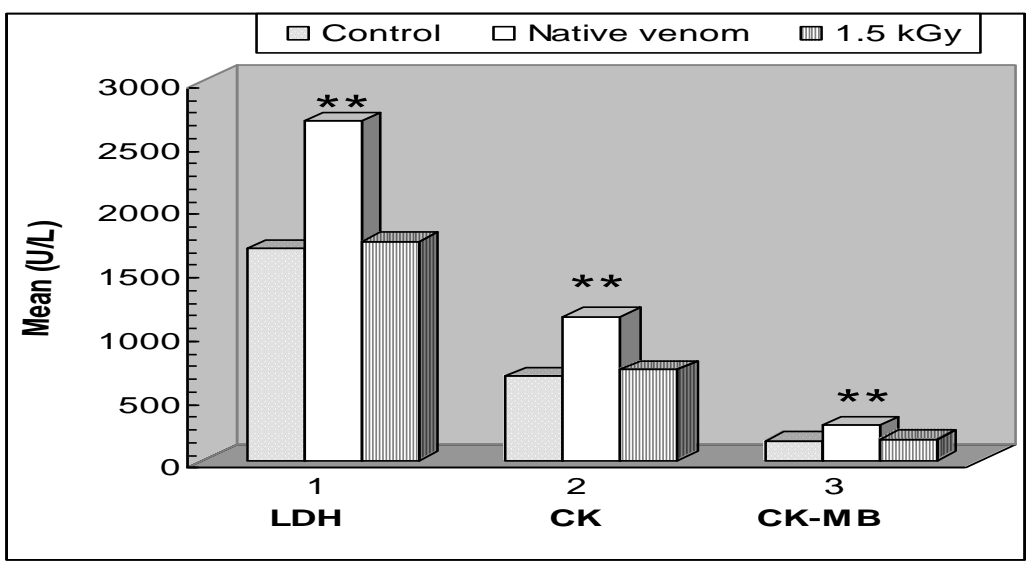

Fig. (3): The mean values of serum levels of lactate dehydrogenase (LDH), creatine kinase (CK) and creatine kinase isoenzyme (CK-MB) for normal control, native and $1.5 \mathrm{kGy} \gamma$ irradiated Echis pyramidum venom envenomated groups (4hr after i.p injection of mice). Each column represents the mean value of fifteen mice.

**: Highly significant increase from normal control.

Table (5): Myotoxic activities of native and $1.5 \mathrm{kGy} \gamma$ irradiated Echis pyramidum venoms. Plasma creatine kinase (CK) activity was determined $3 \mathrm{hr}$ after the intramuscular injection of the native or $1.5 \mathrm{kGy} \gamma$ irradiated venom $(13.8 \mu \mathrm{g} / 50 \mu \mathrm{l})$ in the gastrocenemius muscle of mice $(\mathrm{n}=$ 4). $n$ : Number of mice in each group.

\begin{tabular}{|l|l|l|l|}
\hline $\begin{array}{l}\text { Plasma Groups } \\
\text { (CPK U/L) }\end{array}$ & Control & Native venom & $1.5 \mathrm{kGy}$ \\
\hline Mean \pm SE & $1039 \pm 162.4$ & $4035.2 \pm 411.8$ & $1885 \pm 217.9$ \\
\hline P Value / control & & P $<0.01^{*}$ & N.S. \\
\hline
\end{tabular}

$P<0.01$ : significant. N.S.: Non significant.

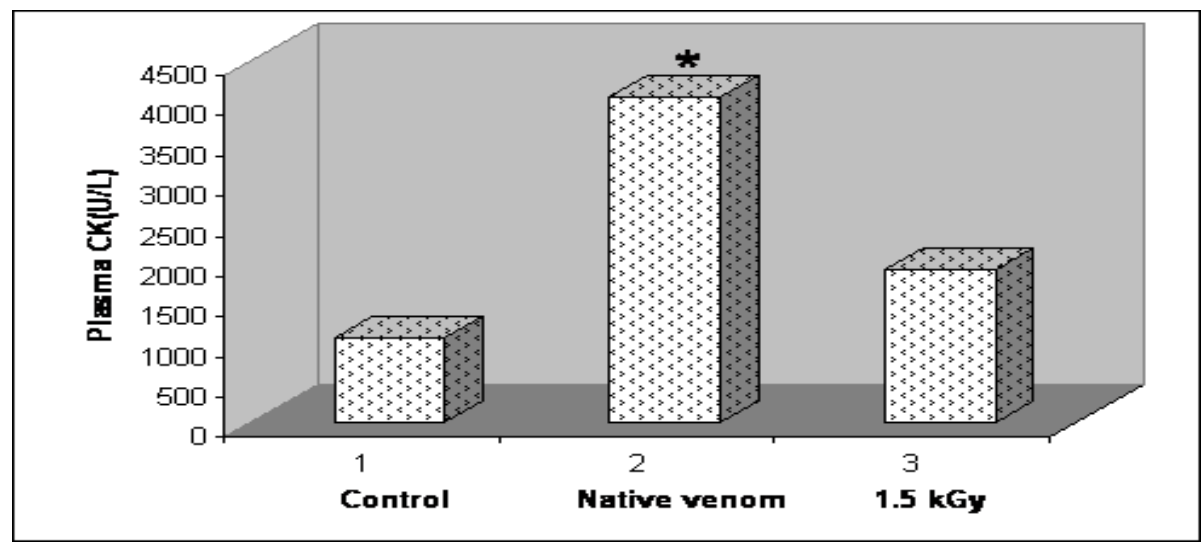

Fig. (4): Myotoxic activities of native and $1.5 \mathrm{kGy} \gamma$ irradiated Echis pyramidum venoms. Plasma creatine kinase (CK) activity was determined $3 \mathrm{hr}$ after the intramuscular injection of the native or $1.5 \mathrm{kGy} \gamma$ irradiated venom $(13.8 \mu \mathrm{g} / 50 \mu \mathrm{l})$ in the gastrocenemius muscle of mice $(\mathrm{n}=$ 4).

*: Significant increase from normal control. 


\section{Influence of ....}

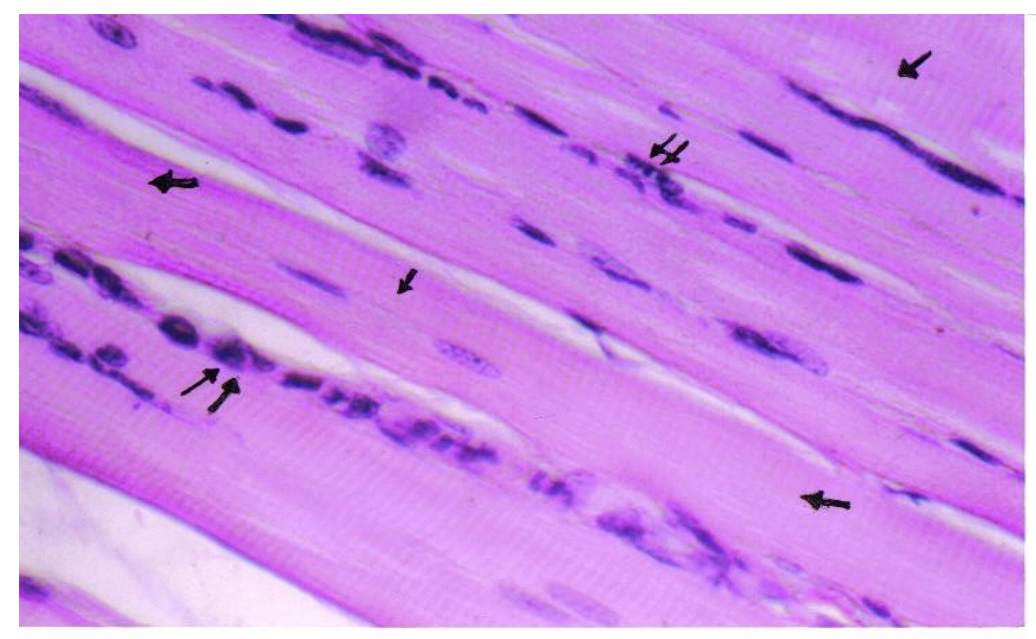

Fig. (5): A photomicrograph of a section of the gastrocenemius muscle of control mice showing bundles of skeletal muscle fibers with evident cross striations ( $\uparrow)$. Notice the peripherally situated multiplenuclei $(\uparrow \uparrow)$, X 640 .

(A)

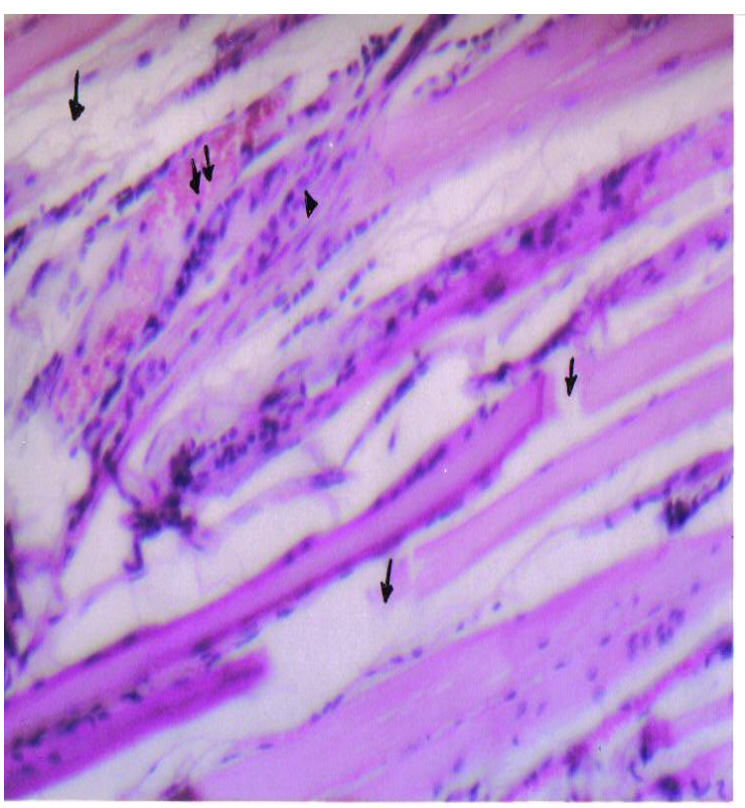

(B)

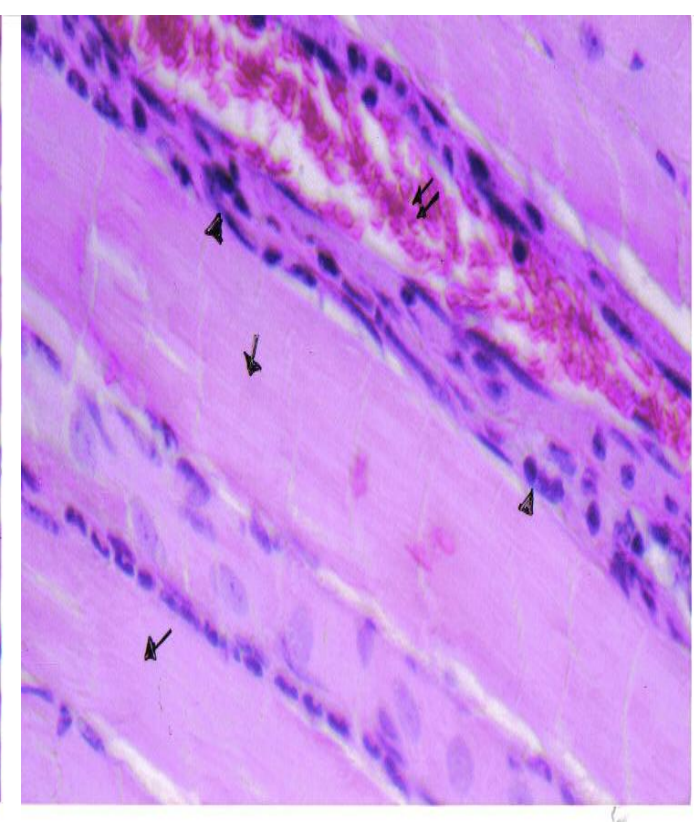

Fig. (6): A photomicrograph of a section of the gastrocenemius muscle of mice treated with native Echis pyramidum venom $(13.8 \mu \mathrm{g} / 50 \mu \mathrm{l})$.

(A) showing fragmentation of muscle fibers $(\uparrow)$. Notice hemorrhage in-between the muscle fibers $(\uparrow \uparrow)$ and mononuclear cellular infiltration $(\Delta)$, X 250 .

(B) showing disorganization and loss of myofibrils in some of the muscle fibers $(\uparrow)$. Notice hemorrhage in-between the muscle fibers $(\uparrow \uparrow)$ and mononuclear cellular infiltration $(\Delta), \mathrm{X} 640$. 
(A)

(B)

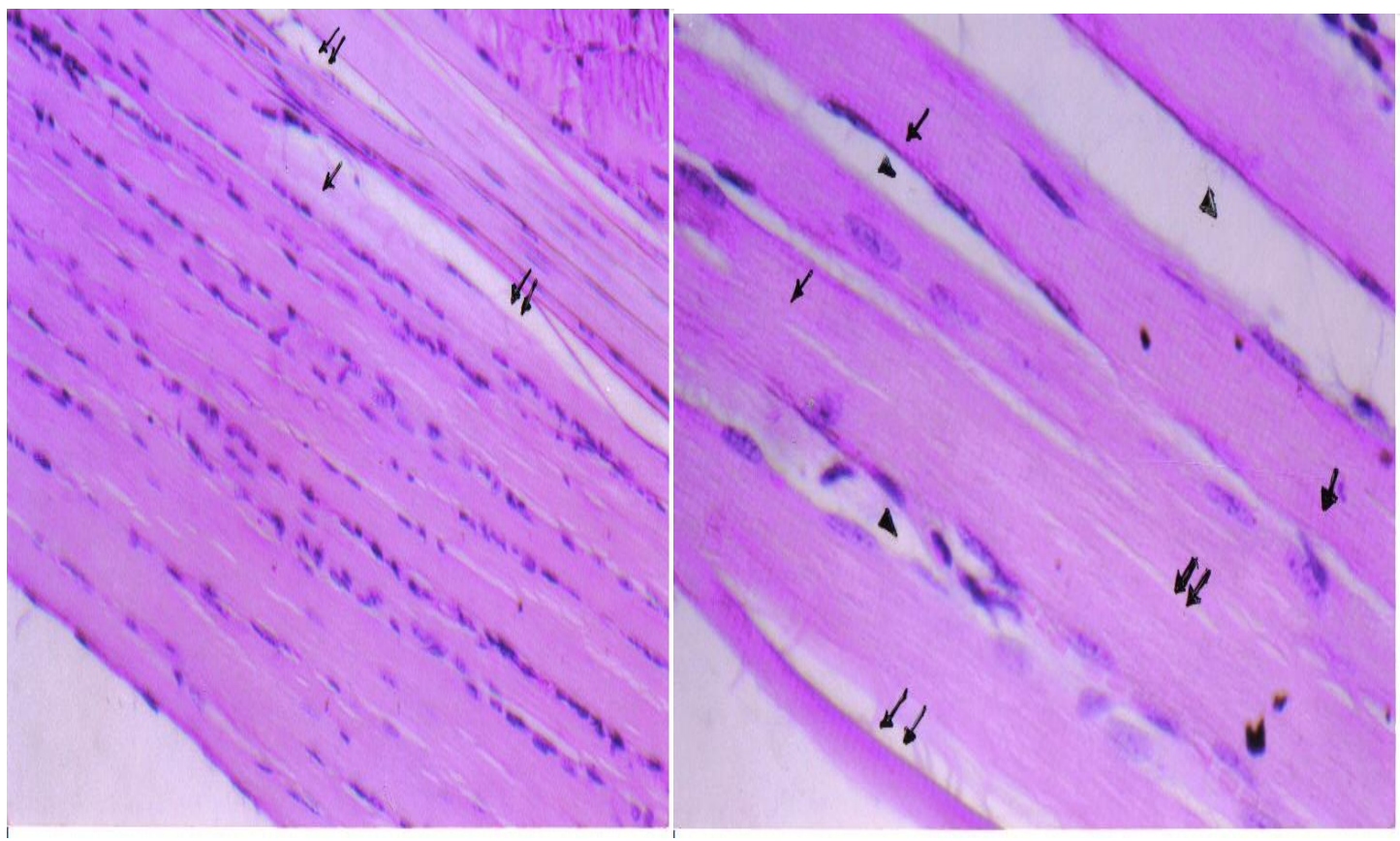

Fig. (7): A photomicrograph of a section of the gastrocenemius muscle of mice treated with 1.5 $\mathrm{kGy} \gamma$ irradiated Echis pyramidum venom $(13.8 \mu \mathrm{g} / 50 \mu \mathrm{l})$.

(A) showing most of the muscle fibers were of normal appearance except for small area of fragmentation $(\uparrow)$. Notice the oedema of the intercellular connective tissue $(\uparrow \uparrow), X 250$.

(B) showing most of the muscle fibers were of normal appearance with evident cross striations $(\uparrow)$. Notice small area of disorganized myofibrils $(\uparrow \uparrow)$ with intercellular connective tissue oedema $(\Delta)$, X 640.

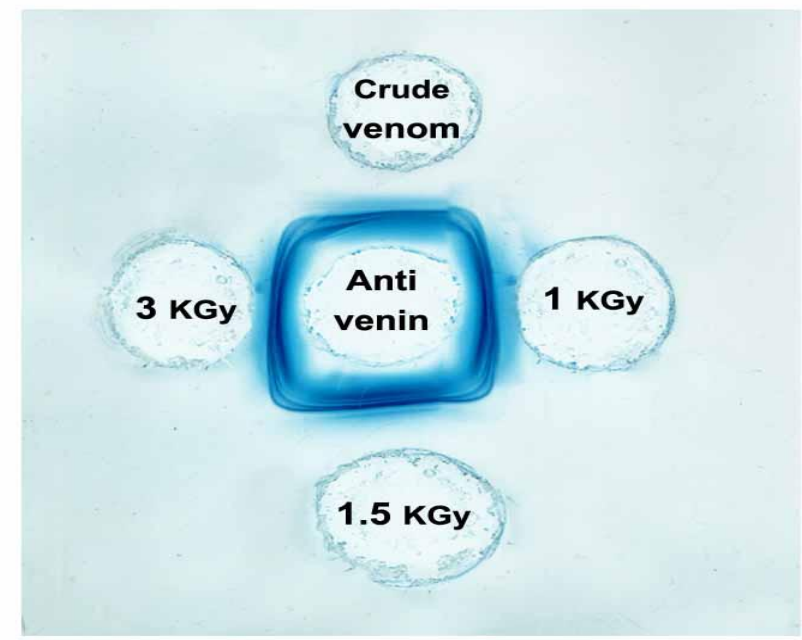

Fig. (8): The immunogenic reactivity of horse polyvalent antivenin (in the central well) against native, $1,1.5$ and $3 \mathrm{kGy} \gamma$ irradiated Echis pyramidum venoms $(20 \mathrm{mg} / \mathrm{ml})$. 
1

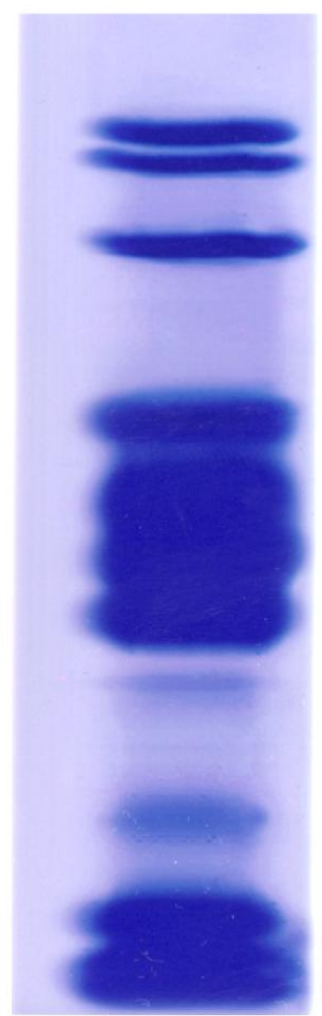

2

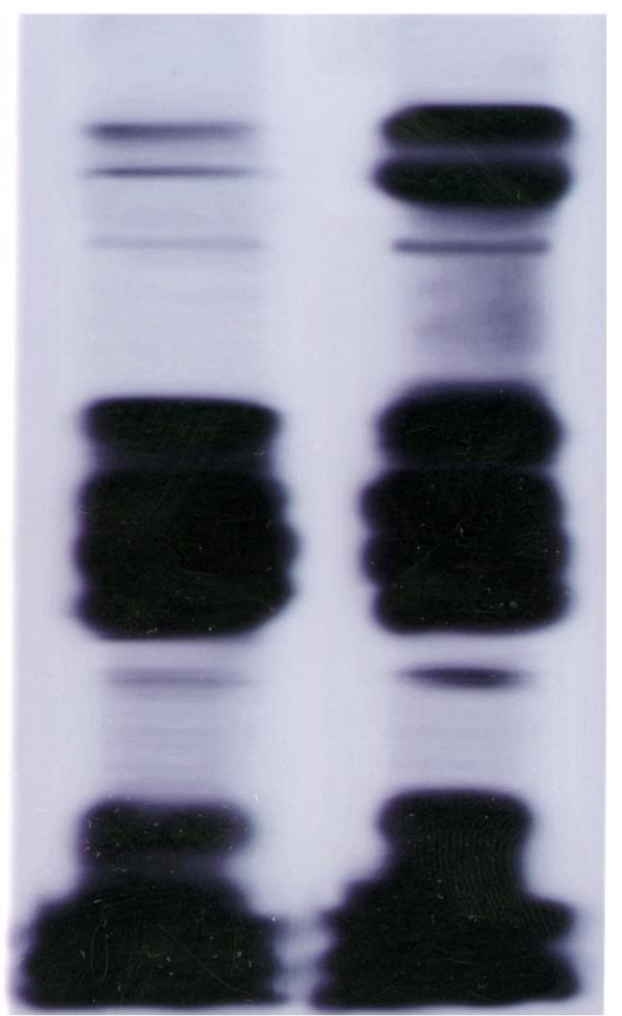

Fig. (9): Western blotting of antivenin raised against native and $1.5 \mathrm{kGy} \gamma$ irradiated Echis pyramidum venom: samples of $20 \mu \mathrm{g}$ of native Echis pyramidum venom (column 1) were submitted to Western blotting and revealed by antivenin raised against native (column2) and antivenin raised against $1.5 \mathrm{kGy} \gamma$ irradiated Echis pyramidum venom (column 3).

\section{Discussion:}

The performed experiment assessed the impact of $\gamma$ irradiation of Echis pyramidum venom on the effects induced by the venom on some biochemical markers. The present work showed the effects of $\mathrm{LD}_{50}$ $(27.69 \mu \mathrm{g} / \mathrm{mouse})$ of native Echis pyramidum venom on some biochemical parameters.

The activities of Aspartate aminotransferase (AST), Alanine aminotransferase (ALT) and Alkaline phosphatase (ALP) underwent a highly significant increase following envenomation with native Echis pyramidum venom compared to the normal control. The results are in agreement with prior reports. Sant et al. (1974) and Tembe et al. (1975) by using Echis Carinatus snake venom found that there were elevations in the serum concentration of AST, ALT and ALP in animals four hours post envenomation in comparison with the control group. Also, it was reported by Abdel - Nabi and Rahmy (1992), using Echis carinatus venom, that injection of sublethal dose caused a significant rise in serum AST, ALT and ALP in rats accompanied with disturbances in the hepatic and renal functions of the envenomated animals through severe hepatocellular injuries, necrosis of hepatocytes and kidney tubules as well as nephrotoxic action. Moreover, Shaban and Hafez (2003) reported that intraperitoneal injection of a sublethal dose of Naja haje venom $(0.2 \mathrm{mg} / \mathrm{kg})$ in rats induced a significant elevation in the activities of AST, ALT and ALP as compared to normal control. Furthermore, Abdel-Nabi (1993) reported that the sublethal dose of both crude venom and its B fraction injection caused a significant elevation in AST, ALT and Alkaline phosphatase (ALP) activities. 
This elevation in the ALP could be attributed either to the destruction of the liver, kidney and/or heart tissue. Also elevation in AST and ALT, gives evidence about the destruction of the hepatocytes as a result of venom injection. Also Mohamed et al, (1981) reported that Bitis arietans venom significantly increased AST and ALT levels in serum while decreased them in liver, heart and kidney. Similarly, alkaline phosphatase levels increased in serum and decreased in heart and liver.

As for the effect on the kidney and renal functions, the $\mathrm{LD}_{50}(27.69 \mu \mathrm{g} / \mathrm{mouse})$ of native Echis pyramidum venom induced a highly significant increase in urea and creatinine concentrations compared to the normal control.

The recorded results are in accordance with those found by Abdel Nabi 1993 who has reported that a sublethal dose of both crude Cerastes cerastes venom and its B fraction showed a significant rise in blood urea nitrogen and this was concomitant to a significant increase in serum creatinine levels as well. The increase in these values is used as an indicator of renal failure.

In other studies on the effect of the viper Cerastes cerastes cerastes venom on the kidney, Abdel - Aal ( 1998 ) reported that viper venom increased serum creatinine and urea significantly, $30 \mathrm{~min}$. following injection, and that this effect persisted for up to 7 days, indicating renal failure. Also, Tu (1991) and Merchant et al. (1989), reported that renal diseases caused by various snake venoms were characterized by raised urea , creatinine and potassium in oliguric patients. Moreover, Shaban and Hafez '(2003) reported that intraperitoneal injection of a sublethal dose of Naja haje venom $(0.2 \mathrm{mg} / \mathrm{kg})$ in rats induced a significant elevation in the activities of urea and creatinine as compared to normal control. This significant elevation was attributed to the nephrotoxic effect of venom. This was in agreement with the findings of Rahmy et al. (1992 \& 1995b) and Yaguchi et al. (1996). They mentioned that serious renal complications in case of Naja haje and Cerastes cerastes envenomation lead to impairment of the excretory function of the kidney.
Significant elevation in serum urea recorded in this work may also be attributed to an increase of nitrogen retention and / or due to corrupted renal function (Abdel Nabi 1993).

As for the effect on heart enzymes, the present study indicated that the $\mathrm{LD}_{50}(27.69$ $\mu \mathrm{g} /$ mouse) of native Echis pyramidum venom caused a highly significant increase of Lactate Dehydrogenase (LDH), Creatine Phosphokinase (CPK) and Creatine Phosphokinase isoenzyme (CKMB)compared to the normal control. The obtained results are in agreement with those previously reported by other investigators. Aguiyi et al. (2001) reported an elevation in the levels of Lactate Dehydrogenase (LDH) and Creatine Phosphokinase (CPK) following administration of Echis carinatus venom. Also, Fernando et al. (1989) reported that B. asper venom caused serum AST, LDH and CPK to increase significantly, the highest peak being observed at $3 \mathrm{hr}$ in the cases of AST and CPK, and at $6 \mathrm{hr}$ in the case of LDH. The CPK isoenzymes, samples taken at $3 \mathrm{hr}$ showed a prominent increase in isoenzyme CK-MM with a slight increase in CK-MB. Moreover, Sofer et al., (1991) reported that the enzymatic activity of Creatine kinase MB isoenzyme and total Creatine Phosphokinase (CPK) were elevated following envenomation by the scorpion Leiurus quinquestriatus in children. They speculated that the myocardial lesions are too small to cause heart failure in most cases, but they may account for the cardiovascular changes frequently seen in scorpion envenomation. This assumption was also confirmed by the findings of Hering et al., (1993) and Correa et al., (1997), who reported an increase in the levels of CPK and LDH in patients stung by Tityus serrulatus scorpion and showed a cardiomyopathy picture. Shaban and Hafez (2003) reported that the intraperitoneal injection of a sublethal dose of Naja haje venom $(0.2 \mathrm{mg} / \mathrm{kg})$ in rats induced a significant elevation in the activities of $\mathrm{LDH}$ and CK-MB as compared to normal control.

Mohamed et al., (1981) reported the effect of lethal doses of five venoms (Bitis 
arietans, Bitis gabonica, Dendroaspis, Naja nigricollis and Naja haje) on the activities of transaminases, alkaline phosphatase and lactate dehydrogenase in albino rats. The activity of these enzymes were markedly increased in serum and variably decreased in the liver, heart and kidney after envenomation.

Measurement of enzyme activity in serum is of importance since it helps to assess the state of the liver and other organs. Normally serum transaminase levels are low, but after extensive tissue injury, these enzymes are liberated into the serum and the levels of serum transaminase, were reported to be increased following damage to skeletal muscles, myocardial muscles and liver (Harper et al. 1977). It was suggested that, tissue destruction occurred in most of the organs secondary to venom injections. The increase in enzymatic activity of the serum might be due to release of the enzymes from liver, kidney and heart (Metzler, 1977).

The rapid rise in ALT and AST activities recorded in the present study $4 \mathrm{hr}$ after venom envenomation may be attributed to severe injuries and necrosis of hepatocytes as well as to a nephrotoxic action of the venom as reported by Abdel Nabi (1993). Also, Kadryov (1987) and Omran and Abdel Rahman (1992), reported that lethal and sublethal doses of venom were capable of stimulating stress reactions. Cortisol and catecholamines are the main hormones released in response to stress and increased levels of these hormones in victims circulation may cause sever damage in many vital organs proportional to the dose of the venom and the elapsid time. Organ damage is followed by an increase in levels of ALT, AST and ALP (Omran et al., 1997). Rahmy and Hemmaid (2000 \& 2001) reported that Cobra venom induced a hepatotoxic action reflected by alteration in the histological and histochemical patterns of the hepatic tissues. These alterations are initiated at early stages of envenomation and could indicate a disturbance in the functional activities of the liver during envenomation.

Interestingly, the $1.5 \mathrm{kGy} \gamma$ irradiated Echis pyramidum venom caused a non significant change (when used at a dose equal to that used for the native venom; 27.69 $\mu \mathrm{g}$ /mouse) of ALT, AST, ALP, urea, creatinine, $\mathrm{LDH}, \mathrm{CPK}$ and $\mathrm{CK}-\mathrm{MB}$ compared to the normal control. This was in contrast to the native Echis pyramidum venom (27.69 $\mu \mathrm{g} /$ mouse) that induced a highly significant increase of ALT, AST, ALP, urea, creatinine, LDH, CPK and CKMB compared to the normal control or the 1.5 kGy $\gamma$ irradiated Echis pyramidum venom.

After injection of muscle directly, we found that $1 / 2 \mathrm{LD}_{50}(14 \mu \mathrm{g} / 50 \mu \mathrm{L})$ of native Echis pyramidum venom induced a significant increase of creatine kinase (CPK), released from the gastrocnemius muscles, compared to normal control. In contrast, an equal dose of $1.5 \mathrm{kGy} \gamma$ irradiated Echis pyramidum venom showed a non significant increase of creatine kinase when compared to normal control. Moreover, the elevation in CPK levels observed with native Echis pyramidum venom $(14 \mu \mathrm{g} / 50 \mu \mathrm{l})$ was highly significant compared to the $1.5 \mathrm{kGy} \gamma$ irradiated venom as well. These results indicate a decrease in the myotoxicity of the $\gamma$ irradiated Echis pyramidum venom.

Gutiérrez and Lomonte (1995) reported that myotoxic effect of venoms of the genus Bothrops is particularly important, not only because it may lead to permanent tissue loss, disabling the victim, but also because it may induce severe cutaneous lesions on the animals chronically exposed to the venom during the immunization process.

Souza et al. (2002) investigated the ability of gamma radiation from ${ }^{60} \mathrm{Co}(2 \mathrm{kGy})$ to attenuate the toxic effects of Bothrops jararacussu venom on mouse neuromuscular preparations in vitro. It was concluded that ${ }^{60} \mathrm{Co}$ gamma radiation is able to abolish both the paralyzing and the myotoxic effects of Bothrops jararacussu venom on the mouse neuromuscular junction. These findings support the hypothesis that gamma irradiation could be an important tool to improve antisera production by reducing toxicity while preserving immunogenicity.

Irradiation of crotoxin was shown to result in its aggregation and generation of low molecular weight breakdown products 
(Nascimento and Rogero 1995). The aggregates presented no toxicity, no phospholipase activity and no ability to promote creatine kinase $(\mathrm{CPK})$ release into muscle tissue.

Histological analysis of gastrocnemius muscles subjected to native Echis pyramidum venom revealed a large number of muscle fibers drastically affected by the formation of dense clumps of hypercontracted myofibrils alternating with areas of cytoplasm apparently devoid of myofibrils. On the other hand, histological analysis of gastrocnemius muscles subjected to $\gamma$ irradiated venom revealed a large number of fibers with normal appearance and only few muscle cells presenting edema in the connective tissue.

Injection of a sublethal venom dose in rats produced severe degeneration of muscle fibers and loss of striations, also, hemorrhage and extravasated red blood cells were seen in between the myocardial bundles as recorded for several venoms by $\mathrm{Tu}$ and Homma (1970), Rahmy et al. (1995a \& b) and Hanafy et al. (1999). In the present work the hemorrhage observed in between the muscle receiving the native venom may be due to increased intravascular tension or venous congestion (Willoughly, 1960).

Collectively, the present data support the conclusion that gamma radiation is an effective venom-detoxification method which could help solve the chronic problems of anti ophidic sera production. Results from the double immunodiffusion test revealed a similar reactivity for native, $1 \mathrm{kGy}, 1.5 \mathrm{kGy}$ and $3 \mathrm{kGy} \gamma$ irradiated Echis pyramidum venoms against a commercial polyvalent Egyptian antivenin. The visible lines obtained in the immunodiffusion reactions were identical and join smoothly at the corners, indicating that there was no change in their antigenic reactivity. These results demonstrate that the ability of the venom antigens to react with its corresponding antibodies was maintained in spite of being exposed to radiation doses of $1 \mathrm{kGy}, 1.5 \mathrm{kGy}$ and 3 kGy.

The recorded results are in agreement with those concluded by Shaban et al., (1996).
They indicated that there was no change in antigenic reactivity with antibodies determinants. Also Shaban (2003) reported that immunodiffusion studies revealed identity between $\gamma$ irradiated (15 kGy) and native Naja haje and Cerastes cerastes venoms since the antigenic response was not changed as judged by the capacity of irradiated venoms to react with horse polyvalent antivenin. Moreover, BennacefHeffar and Laraba-Djebari (2003) showed that the effect of gamma irradiation on the venom of Vipera lebetina (one of the two widespread snakes in Algeria). Vipera lebetina venom was irradiated with two doses of gamma rays ( 1 and $2 \mathrm{kGy}$ ) from a ${ }^{60} \mathrm{Co}$ source, and the venom's toxic, enzymatic, and structural properties were analyzed. Intraperitoneal injection of the irradiated venoms (100-500 $\mu \mathrm{g} / 20 \mathrm{~g}$ mouse body mass) revealed a significant decrease in its toxicity. Irradiated venoms with 1 and $2 \mathrm{kGy}$ doses were four and nine times less toxic, respectively, than the native venom. Moreover, the caseinolytic, amidolytic, esterasic, and coagulative activities venom were reduced following irradiation only phospholipase $A_{2}$ activity was abolished in the irradiated venom with a dose of $2 \mathrm{kGy}$. Both chromatographic and electrophoretic profiles of the irradiated venom were drastically changed as compared with that of the native venom. The gamma rays detoxified venom was then used for active immunization, and the presence of antibody in the immune sera was detected by ELISA. The immunogenic properties of the irradiated venom were preserved and the antisera obtained were able to neutralize the toxic effect of Vipera lebetina native venom. These results indicate that irradiation of Vipera lebetina venom with a dose of $2 \mathrm{kGy}$ can promote a significant detoxification while keeping the immunological properties intact). Irradiation of Vipera lebetina venom with a dose of $2 \mathrm{kGy}$ can promote a significant detoxification while keeping the immunological properties intact. Furthermore, Nascimento et al. (1998) reported that ionizing radiation is able to detoxify several venoms, including snake venoms, without affecting their 
immunogenic properties significantly. However, Kume and Matsuda (1995), studying the radiation induced changes in the structural and antigenic properties of egg albumin and bovine serum albumin, suggested that the main part of conformation-dependent antigenic structures (conformational epitopes) is easily lost by radiation, but some antigenicity, which is mostly due to the amino acid sequence-dependent antigenic structures (sequential epitopes) remains, even at high doses.

Finally, both antivenins recognized Echis pyramidum venom when submitted to protein blotting, but the anti $1.5 \mathrm{kGy} \gamma$ irradiated venom show a higher intensity bands than the antivenin raised against native Echis pyramidum venom. In spite of has less neutralizing activity (native neutralize $50 \mathrm{LD}_{50}, 1.5 \mathrm{kGy} \gamma$ irradiated neutralize $40 \mathrm{LD}_{50}$ ), this indicate that antibodies were formed not only for toxic fraction but also for non toxic fraction.

These results agree with those of Clissa et al. (1999) who reported that antivenin raised against the native venom and the 2 kGy $\gamma$ irradiated venom recognized equally all the bands present on the native Crotalus durissus terrificus venom, but the ELISA titre of recognition for each toxin was higher for the serum anti-2 kGy $\gamma$ irradiated venom than for the serum anti-native venom. In order to ensure that the improvement in immunogenicity of $2 \mathrm{kGy} \gamma$ irradiated venom was due to the presence of aggregates and not to minor amounts of intact proteins left after irradiation, they produced an antiserum against native Crotalus durissus terrificus venom following an immunization protocol in which the amount of intact protein injected was similar the amount of intact protein present in the $2 \mathrm{kGy} \gamma$ irradiated venom. The antiserum obtained in this way had a low ELISA titre and low neutralizing ability (Clissa et al. 1999).

In conclusion irradiation of the whole Echis pyramidum venom with $1.5 \mathrm{kGy}$ reduced its lethality 12.7 times while a higher dose of radiation $(3 \mathrm{kGy})$ destroyed practically all the venom toxicity though keeping its immunogenicity. However, the $1.5 \mathrm{kGy}$ dose was shown to be the best radiation dose to promote venom detoxification without significantly affecting its immunogenicity. Thus, our present results confirm the conclusion that $\gamma$ radiation is a suitable way to detoxify the Echis pyramidum venom without affecting its immunogenicity provided that a proper dose is used.

Moreover, these neutralization studies on the antivenin raised against the $1.5 \mathrm{kGy} \gamma$ irradiated venom demonstrate the ability of the detoxified venom to be used as an alternative to crude venom in immunizing horses even in the initial doses of immunization before immunity build up.

\section{References}

1. Abu-Sinna G, Abdel-Aal A, Al-Zahaby A S and Soliman N A (1992). The effect of Cerastes cerastes venom on aldolase, lactate dehydrogenase and isocitrate dehydrogenase activities of the serum and tissues of the white rat. Proc. Zool. Soc., 23:25-27.

2. Abdel-Aal A (1998). Effect of Cerastes cerastes venom on some biochemical parameters in serum and urine of rats. J. Egypt. Ger. Soc. Zool., 26 (A):41-58

3. Abdel-Aal A, Abu-Sinna G, Al-Zahaby A S, Abdel-Baset A and Soliman N A (1992). The effect of Cerastes cerastes venom on the protein and lipid of the white rats. J Egypt Germany Soc. Zool., 9:137-148.

4. Abdel-Nabi I M (1993). Effect of crude Cerastes cerastes venom and fraction $\mathrm{B}$ on the clinical parameters of white rat. J Egypt. Ger. Soc. Zool., 10 (A):315-326.

5. Abdel-Nabi I M and Rahmy T R (1992). Influence of the venom of the snake Echis carinatus on the structure and function of the hepatic tissues of white rat. J Egypt. Ger. Soc. Zool (C)., 171-187.

6. Abu-Sinna G, Al-Zahaby A S, Abdel-Aal A, Abdel Baset, A. and Soliman, N A (1993). The effect of the viper Cerastes cerastes venom and venom fractions on carbohydrate metabolism. Toxicon, 31:791-801.

7. Aguiyi J C, Guerranti R, Pagani R, Marinello E. (2001). Blood chemistry of rats pretreated with Mucuna pruriens seed aqueous extract Mp 101 UJ after Echis carinatus venom challenge. Phyto ther Res., 15 (8): 712-4.

8. Artashes V A and Silva, V A (2006). Histopathological changes induced by the venom of the snake Vipera raddei (Armenian 
adder)

Toxicon,

47 (2):141-143.

9. Baride M, Jain S D and Gaitonde B B (1980). Biochemical studies on toxoids of venoms of poisonous Indian snakes. Indian. J Med Res., 72: 571-576.

10.Bennacef-Heffar $\mathrm{N}$ and Laraba-Djebari $\mathrm{F}$ (2003). Evaluation of the effect of gamma rays on the venom of Vipera lebetina by biochemical study. Can. J. Physiol. Pharmacol./Rev. Can. Physiol. Pharmacol., 81 (12):1110-1117.

11. Cliss $\mathrm{PB}$, Nascimento $\mathrm{N}$, Rogero $\mathrm{J} R$, (1999). Toxicity and immunogenicity of Crotalus durissus terrificus venom treated with different doses of gamma rays. Toxicon, 37 (8):1131-1141.

12. Correa M M, Sampaio S V, Lopes R A, Mancuso L C, Cunha O A, Franco J J and Giglio J R (1997). Biochemocal and histopathological alterations induced in rats by Tityus serrulatus scorpion venom and its major neurotoxin Tityustin - 1. Toxicon, 35 (7):10531067.

13. Costa L M, Takeda A K, Barbosa S F C, Berra J A P, Adelina M G F, Soerensen B, Pinto, J R, Vancetto, M D C (1985). Study of immune response in horse immunized with Crotalus durissus terrificus, in natura, submitted to formaldehyde treatment and thermic action. Vacinas Soros 1:24-29.

14. Daniel J P, Heneine L D G, Tavares C P A, Nascimento M C S and Heneine I F (1987). Generation of protective immune sera by Crotalus durissus terrificus venom detoxified by controlled iodination. Braz. J. Med. Biol.Res., 20:713-720.

15.Drury R A B and Wallington E A (1976). Haematoxylin and eosin stain technique. Carlaton's Histological Technique, $4^{\text {th }}$ ed., Oxford University Press, London, New York, Toronto 128-129.

16. Fernando C, Jose M G, Bruno L and Luis C (1989). Histopathological and biochemical alterations induced by intramuscular injection of Bothrops Asper venom in mice. Toxicon, 27 (10):1085-1093.

17. Freitas T V and Fr'ezard F (1997). Encapsulation of native crotoxin in liposomes: a save approach for the production of antivenom and vaccination against crotalus durissus terrficuus venom. Toxicon, 35:91-100.

18. Gallacci M, Nascimento N, Rogero J R and Vassilieff V S (2000). Influence of temperature upon effects of crotoxin and gamma-irradiated crotoxin at rat neuromuscular transmission. Toxicol. Lett 114:77-80.

19. Gutiérrez J M and Lomonte B (1995). Phospholipase $\mathrm{A}_{2}$ myotoxins from Bothrops snake venoms. Toxicon, 33:1405-1424.

20.Hanafy M S, Rahmy N A and Abd ElKhalek, M. M. (1999). The dielectric properties of neutron irradiated snake venom and its pathological impact. Med. Biol., 44:2343-2364.

21. Harper C, Harold A, Victor WR, Odwell B and Peter A (1977). Review of physiological chemistry $16^{\text {th }}$ ed. International standard Book number 0.87041-0.34-2.Los Altos, California, 94022 p 456-462.

22. Harrison $\mathrm{R}$ A, Hasson $\mathrm{S} S$, Harmsen $M$, Laing G D, Conrath K and Theakston R D G (2006). Neutralisation of venom-induced haemorrhage by IgG from camels and llamas immunised with viper venom and also by endogenous, non-IgG components in camelid sera. Toxicon, 47 (3):364-368.

23. Henry R J (1974). Clinical chemistry, principles and techniques, $2^{\text {nd }}$ Edition, Harper and row. P525.

24.Hering F S, Jurea M, Vichi F L, AzevedoMarques, M. M. and Cupo, P. (1993). Reversible cardiomyopathy in patients with severe scorpion envenoming by Tityus serrulatus: evolution of enzymatic, electron cardiographic and echocardiographic alterations. Am. Trop. Paediatr.,13: 173-182.

25. IFCC (1980): Measurement of Lactate dehydrogenase in serum. Journal of Clinic Chemistry Clinical Biochemistry 18:521.

26. Kadryov I K (1987). An electron microscope study of adrenal cortex in rats envenomated by middle Asian gurza venom (Viper lebtina). Toxicon, 16: 673 .

27. Kume T and Matsuda T (1995). Changes in structural and antigenic properties of proteins by radiation. Radiat. Phys. Chem., 46:225-231.

28. Merchant M R, Khanna U B, Almedia A F, Acharya V N and Mittal B V (1989). Clinicopathological study of acute renal failure following Viperine snake bite. Assoc. Physicans India., 37:430-433.

29. Metzler D E (1977). Biochemistry. The chemical reactions of living cells. Academic Press, New York. Harper.

30. Millon G S, Corbert J J , and MC Teer P M (1986): Introduction to Stati-6-Stics $3^{\text {rd }}$ edition D.C. Healthy and company, Canada.

31. Mohamed A H, Fouad S, El-Asmar M F, Abdel-Aal A, Hassan A, Zahran F and Abbas N (1981). Effects of several snake venoms on serum and tissue transaminases, alkaline phosphatase and lactate dehydrogenase. Toxicon, 19:605-609.

32.Moroz C, Goldblum $\mathrm{N}$ and DE VRIES A (1963). Preparation of Vipera palestinae antineurotoxin using carboxymethylcellulose- 
bound neurotoxin as antigen. Nature, 200: 697698.

33. Murata $Y$, Nishikawa A $K$, Nascimento N, Higashi H G Dias Da Silva W and Roger J R (1990). Gamma radiation reduces the toxic activities of Crotalus durissus terrificus venom but does not affect their immunogenic activities. Toxicon, 28:617.

34. Nascimento N and Rogero J R (1995). Detoxification of snake venom using ionizing radiation. J. Venom. Anim. Toxins., 1 . (1).

35. Nascimento N, Seebart C S, Francis B, Rogero J R and Kaiser I I (1996). Influence of ionizing radiation on crotoxin: biochemical and immunological aspects. Toxicon, 34:123-131.

36. Nascimento N, Spencer P J, Andrade H F, Guarnieri M C, and Rogero J L (1998). Effects of gamma radiation on snake venoms. Radiation Physics and Chemistry, 52 (1-6): 665- 669.

37. Omran M A and Abdel Rahman M S (1992). Effect of scorpion Leiurus quiquestriatus venom on the clinical chemistry parameters of the rat. Toxicol. Lett., 61:99-109.

38. Omran M A, Abdel Nabi I M and El Naggar M H (1997): Serum Biochemical and Hormonal parameters for the toxic effects of Egyptian Corba (Naja hage) envenomation. J. Nat. Toxins, 6:69-83.

39. Ouchterlony O (1945). In vitro method for testing the toxin production capacity of diphtheria bacteria Acta Path. Microbiol. Scand. 25:186.

40.Patton C J and Crouch S R (1977). Sprctro photometric and kinetics investigation of the berchelot reaction for the determination of ammoniea Anal. Chem. 49:464-469.

41. Rahmy T R and Hemmaid K Z (2000). Histological and histochemical alteration in the liver following intramuscular injection with a sublethal dose of the Egyptian Cobra venom. J. Nat. Toxins, 9:21-32.

42. Rahmy T R and Hemmaid K Z (2001). Prophylactic action of garlic on the histological and histochemical patterns of hepatic and gastric tissues in rats ingected with a snake venom. J. Nat. Toxins, 10:137-165.

43. Rahmy T R, Ramadan R A, Farid T M and El-Asmar M F (1995a). Actions of Cobra venom on cardiac muscles of rats. J. Egypt. Ger. Soc. Zool. 17:235-250.

44. Rahmy T R, Ramadan R A, Farid T M, ElAsmar M F (1995b). Renal lesions induced by Cobra envenomation. J. Egypt. Ger. Soc. Zool. 17:251-271.

45. Rahmy T R, Tu A T, El-Banhawy M, ElAsmar M F and Hassan F M (1992). Cytopathological effect of Cerastes cerastes (Egyptian sand viper) venom and its hemorrhagic toxin on liver and kidney. An electron microscopic study. J. Nat. Toxins, $1: 45-58$.

46. Rec. GSCC (1972): Alkaline phosphates determination method is based on the recommendations of the "German Society for Clinical Chemistry" (GSCC). J. Clin. Chem. Clin. Biochem. 10:182-193

47.REC GSCC (1978): Serum Creatine Kinase determination method is based on the recommendation of " German Society for Clinical Chemistry (GSCC). J. Clin. Chem. Clin. Biochem., 8:658.

48. Reitman A and Frankel S (1957): A

Colorimetric method for the determination of serum glutamic pyruvic transaminase American Journal of Clinical Pathology 28:56.

49. S'anchez E F, Freitas T V, Ferreira-Alves D L, Velarde D T, Diniz M R, Cordeiro M N,

Agostini-Cotta, G. and Diniz, C. R. (1992). Biological activities of venoms from South American snakes. Toxicon, 30:95-103.

50. Sant S M, Tembe V S, Salganokar D S and Purandare N M (1974). Lesions produced by Echis carinatus venom in experimental animals. Postgrad. Med., 21:36-47.

51.Shaban E A and Hafez M N (2003). Ability of gamma-irradiated polyvalent antivenin to neutralize the toxicity of the Egyptian Cobra (Naja haje) venom. The Egyptian Journal of Hospital Medicine, 13:135-152.

52. Shaban E A, Ahmed A A and Ayobe M H (1996). Gamma-irradiated of egyptian Cobra (Naja haje) venom. The Journal of the Egyptian public health association. Vol. 21: 257-271.

53. Reed LJ and Muench H (1938): Simple method of estimating $50 \%$ end points. Am.J.Hyge. 27:493-497.

- Skalka M and Antoni F (1970). Effect of radiation on the biological properties of proteins. In: Radiation Sensitivity of Toxins and Animal Poisons, 1969, Bangkok. Proceedings of a Panel Bangkok. 19-22 May, 1969. International Atomic Energy Agency, Vienna $1-11$.

54. Sofer S, Shahak E, Slonim A and Gueron M (1991). Myocardial injury without heart failure following envenomation by the scorpion Leiurus quinquestriatus in children. Toxicon, 29:382-385.

55. Souza D F A, Spencer P J, Rogero J R, Nascimento N, Dal Pai-Silva M and Gallacci M (2002). ${ }^{60} \mathrm{Co}$ gamma irradiation prevents Bothrops jararacussu venom neurotoxicity and myotoxicity in isolated mouse neuromuscular junction. Toxicon, 40 (8):1101-1106. 
Szasz G and Busch E W (1979). Abstract presented at $3^{\text {rd }}$ Eur. Conger. Clin. Chem., Brighton/UK. 3-8.

56. Tembe V S Sant, S M and Purandare N M (1975). A clino-pathologic study of snake bite cases. Postgrad. Med., 21:36-47.

57. Tietz N W (1976). (ed) Fundamentals of clinical chemistry Saunders, W. B., Co., Philadelphia.

58. Towbin H, Staehelin T and Gordon J (1979). Electrophoretic transfer of proteins from polyacrylamide gels to nitrocellulose sheets: procedure and some applications. Proc. Natl. Acad. Sci., (USA) 76:4350-4354.

59. Tu A T (1991). Tissue damaging effects by snake venom hemorrhage and myonecrosis. In Handbook of Natural Toxins, 5, Tu, A. T., Ed., New York: Dekker, 297-347.
60.Tu A T and Homma, M. (1970). Toxicologic study of snake venom from Costa Rica. Toxicol. Appl. Pharmacol., 16: 73-78.

61. Willoughly D A (1960). Pharmacological aspects of the vascular permeability changes in the rats intestine following abdominal radiation. Br. J. Radiol., 33:515-519.

62. Yaguchi T, Ueda Y and Ishitobi F, (1996). Clincopathological study of the renal damage caused by mamushi snake (Agkistrodan biomhoffi) venom and effects of cepharanthin against it in mice. Dokkyo. Igakks Zasshi, 11: 127-141.

63. Yongming B, Pengchena B, Liji J, Wang H, Qing Y and Lijia A (2005). Purification, characterization and gene cloning of a novel phospholipase $\mathrm{A}_{2}$ from the venom of Agkistrodon blomhoffii ussurensis. Biochemistry and cell Biology, 37:558-565. 


\title{
دراسة التغيرات المناعية والكيميائية الحيوية نتيجة لتأثير الاشعاع الجامى على الحية الغريبة
}

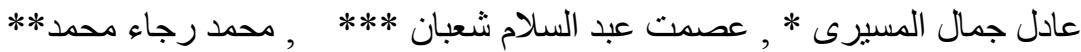

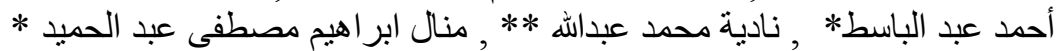 \\ * مركز البحوث الطبية , كلية الطب جامعة عين شمس جلمس

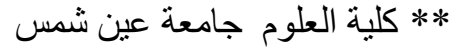 \\ *****المركز القومى لبحوث و تكنولوجيا الاشعاع - هيئة الطاقة الذرية
}

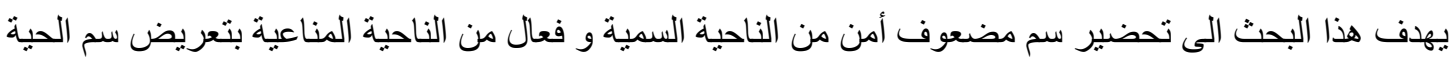

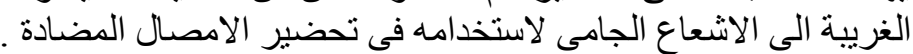

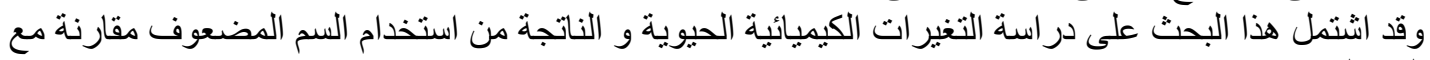

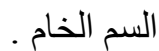
كما تم استخدام السم المضعوف الذى يتم اختياره فى تحضير المصل فى الار انب

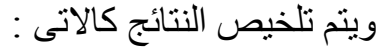

1. وجد ان جر عة سمية الحية الغريبة تمثل مبر 27.79 و و أن هذه النسبة قد زادت مع زيادة التشعيع الجامى مع استخدام جر عة اشعاعية 1.5 kGy كانت السمية 353.23 لكل فأر

2 ـ تجربة الانتشار المزدوج أوضحت أنه لا تغير فى الصفات المناعية باستخدام الاشعاع الجامى ـ فان الخطوط

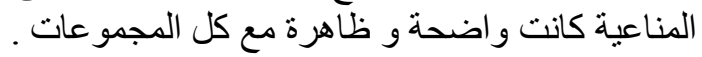

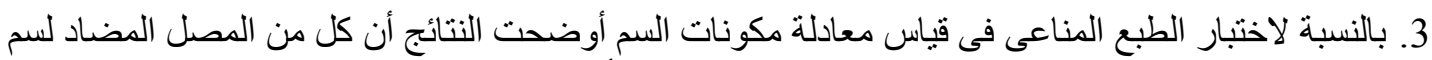

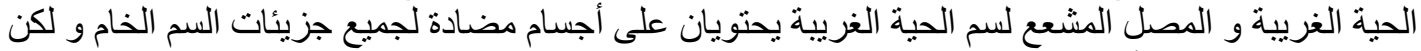
هنالك فرق فى كمية الأجسام المضادة فى كليهما .

4. بالنسبة لنأثثير ات الكميائية الحيوية من ناحية وظائف الكبد وجد أن انزيمات الكبد الناقلة للامين (ALT \&AST)

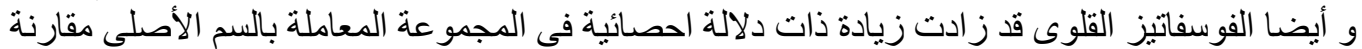

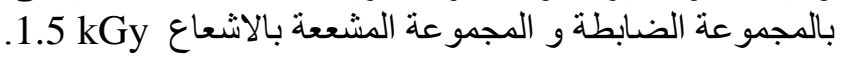

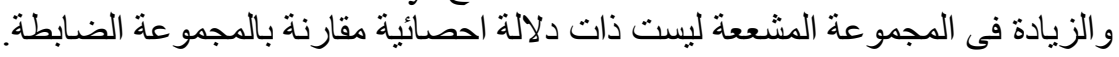

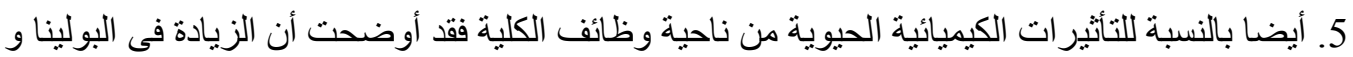

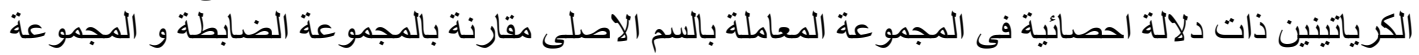

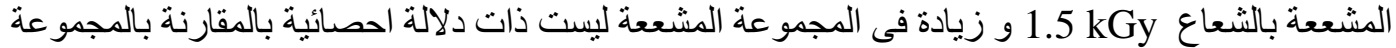
الضابطة ـ اذا التشعيع الجامى قلل من التأثير السمى لسم الحية الغريبة على الكلية.

6. بالنسبة للتأثير ات الكيميائية الحيوية من ناحية وظائف القلب (انزيم اللكتيت ديهيدروجينيز و انزيم كرياتين كيناز

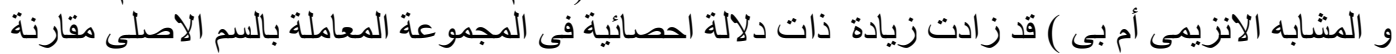

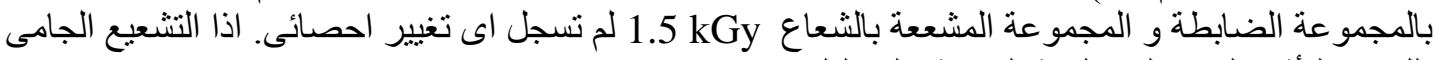
قلل من التأثثر السمى لسم الحية الغريبة على القلب.

7. التأثير السمى لسم الحية الغريبة على عضلة الجاستروكنيميس للفأر أوضح أن انزيم كرياتين كيناز قد زاد فى الفي

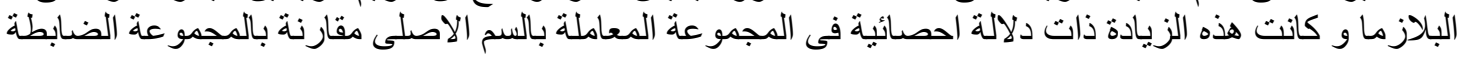

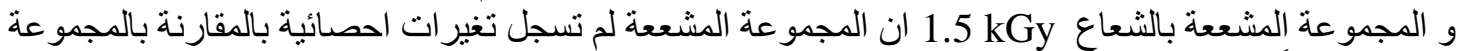

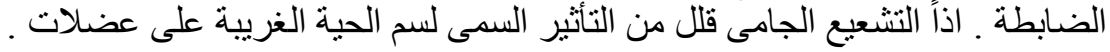




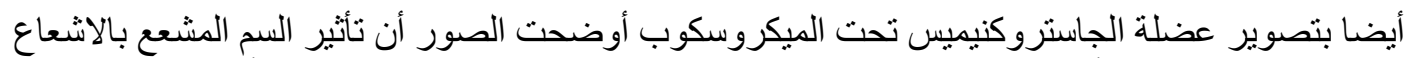

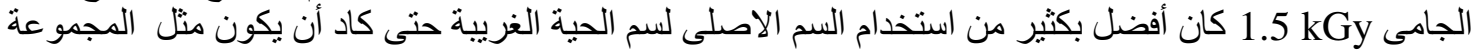

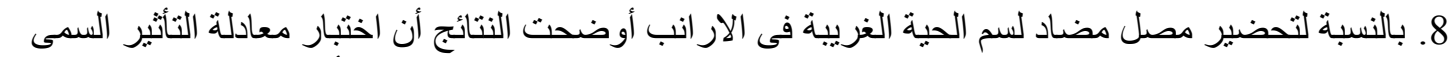

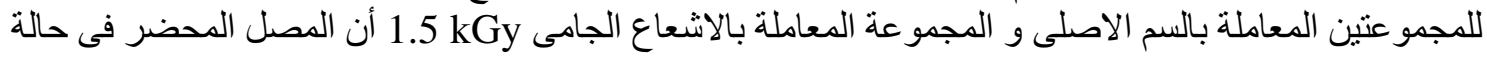

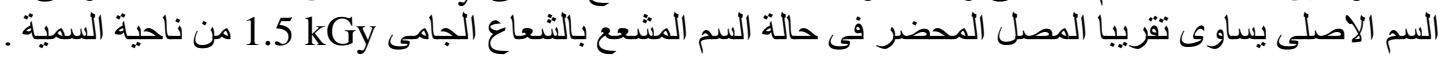

تشير نتائج هذه الدراسة الى أن الجرعة الاشعاعية kGy 1.5 هي الأفضل مع سم الحية الغريبة و يمكن أن تزيل

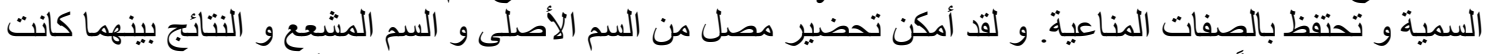
تقريبا متساوية ـ اذاً يمكن استخدام السم المضعوف فى حقن الخيول لتحضير مصل فعال و وأمن للوقاية من سم الحية التية 